\title{
Characterization of ocean biogeochemical processes: a generalized total least-squares estimator of the Redfield ratios
}

\section{Guglielmi ${ }^{1,2}$, C. Goyet ${ }^{1,2}$, and F. Touratier ${ }^{1,2}$}

${ }^{1}$ Images Espace-Dev, University of Perpignan 52, Avenue P. Alduy, 66860 Perpignan, France ${ }^{2}$ Espace-Dev UMR UG UA UM IRD, Maison de la télédétection, 500 rue J.-F. Breton, 34093 Montpellier, France

Received: 16 October 2015 - Accepted: 25 October 2015 - Published: 17 November 2015 Correspondence to: V. Guglielmi (veronique.guglielmi@univ-perp.fr) Published by Copernicus Publications on behalf of the European Geosciences Union.
Characterization of ocean

biogeochemical processes

V. Guglielmi et al.

\section{Title Page}

\section{4}

4

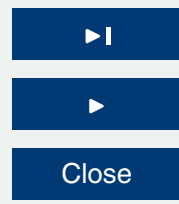

Full Screen / Esc

Printer-friendly Version

Interactive Discussion 


\section{Abstract}

The chemical composition of the global ocean is governed by biological, chemical and physical processes. These processes interact with each other so that the concentrations of carbon dioxide, oxygen, nitrate and phosphate vary in constant proportions, 5 referred to as the Redfield ratios. We build here the Generalized Total Least-Squares estimator of these ratios. The interest of our approach is twofold: it respects the hydrological characteristics of the studied areas, and it can be applied identically in any area where enough data are available. The tests performed on the Atlantic Ocean highlight a variability of the Redfield ratios, both with geographical location and with depth.

10 This variability emphasizes the importance of local and accurate estimates of Redfield ratios.

\section{Introduction}

Most of the elements and the terrestrial chemical compounds (including atmospheric gases) are soluble in the ocean. In the upper ocean, there is a layer called the "mixed 15 layer" because this layer is submitted to movements of turbulence and convection. Its thickness varies from a few tens of meters in summer when surface waters are warm, to several hundred meters in winter when surface waters cool and are moved by violent winds. In 1934, Redfield (1934) was the first to observe that below this mixed layer, the concentrations of carbon dioxide, oxygen, nitrate and phosphate vary in constant proportions, called "Redfield ratios" since.

The commonly admitted explanation for this phenomenon is related to the biological activity of marine microorganisms. Carbon enters into the constitution of every living being, but nitrate $\left(\mathrm{NO}_{3}^{-}\right)$and phosphate $\left(\mathrm{PO}_{4}^{3-}\right)$ are also essential nutrients. At the ocean surface, in the area that receives light, phytoplankton uses the sun's energy to grow. It is photosynthesis, which produces oxygen and transforms carbon dioxide dissolved in seawater, nitrate and phosphate into organic carbon. The reverse reaction is
ESDD

6, 2383-2416, 2015

Characterization of

ocean

biogeochemical

processes

V. Guglielmi et al.

Title Page

Abstract

Introduction

Conclusions References

Tables

Figures

14

$>$ I

4

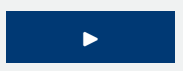

Back

Close

Full Screen / Esc

Printer-friendly Version

Interactive Discussion 
the oxidation of organic matter, or remineralization, which includes the respiration of organisms and, when they die, their decomposition. Below the mixed layer, this oxidation is solely responsible for variations in concentrations of carbon dioxide, oxygen, nitrate and phosphate. That these variations remain in constant ratios means simply that the 5 biological activity follows the same rules everywhere in the ocean.

This is represented by the following chemical reaction:

$$
\begin{aligned}
\mathrm{C}_{\alpha} \mathrm{H}_{\beta} \mathrm{O}_{\gamma} \mathrm{N}_{\delta} \mathrm{P}_{\varepsilon}+\psi_{\mathrm{O}_{2}} \mathrm{O}_{2} \underset{\text { photosynthesis }}{\stackrel{\text { oxidation }}{\rightleftarrows}} & \\
& \psi_{\mathrm{CO}_{2}} \mathrm{CO}_{2}+\psi_{\mathrm{NO}_{3}^{-}} \mathrm{NO}_{3}^{-}+\psi_{\mathrm{PO}_{4}^{3-}} \mathrm{PO}_{4}^{3-}+\psi_{\mathrm{H}^{+}} \mathrm{H}^{+}+\psi_{\mathrm{H}_{2} \mathrm{O}} \mathrm{H}_{2} \mathrm{O} .
\end{aligned}
$$

$\mathrm{C}_{\alpha} \mathrm{H}_{\beta} \mathrm{O}_{\gamma} \mathrm{N}_{\delta} \mathrm{P}_{\varepsilon}$ is a fictitious molecule, which contains the elements entering into the 10 composition of any organic matter. The coefficients $\alpha, \beta, \gamma, \delta, \varepsilon$ are determined by the different stoichiometric coefficients of the reaction: $\psi_{\mathrm{O}_{2}}, \psi_{\mathrm{CO}_{2}}, \psi_{\mathrm{NO}_{3}^{-}}, \psi_{\mathrm{PO}_{4}^{3-}}, \psi_{\mathrm{H}^{+}}$and $\psi_{\mathrm{H}_{2} \mathrm{O}}$.

The Redfield ratios are the ratios of these stoichiometric coefficients. Let us take the example of the concentrations of oxygen and nitrate. When the oxygen concentration 15 decreases by $\Delta \mathrm{O}_{2}$, the concentration of nitrate increases by: $\Delta \mathrm{NO}_{3}^{-}=\frac{\psi_{\mathrm{NO}_{3}^{-}}}{\psi_{\mathrm{O}_{2}}} \Delta \mathrm{O}_{2}$. These concentrations therefore vary according to a constant ratio, called $R_{\mathrm{ON}}$ and defined by:

$R_{\mathrm{ON}}=\frac{\Delta \mathrm{O}_{2}}{\Delta \mathrm{NO}_{3}^{-}}=\frac{\psi_{\mathrm{O}_{2}}}{\psi_{\mathrm{NO}_{3}^{-}}}$.

Similarly, we define the coefficient $R_{\mathrm{OP}}$ :

and the coefficient $R_{\mathrm{NP}}$, which can be deduced from the two previous ones:
ESDD

6, 2383-2416, 2015

Characterization of

ocean

biogeochemical

processes

V. Guglielmi et al.

\section{Title Page}

Abstract Introduction

Conclusions References

Tables Figures

14

4

Back

Full Screen / Esc

Printer-friendly Version

Interactive Discussion 
$R_{\mathrm{NP}}=\frac{\Delta \mathrm{NO}_{3}^{-}}{\Delta \mathrm{PO}_{4}^{3-}}=\frac{\psi_{\mathrm{NO}_{3}^{-}}}{\psi_{\mathrm{PO}_{4}^{3-}}}=\frac{R_{\mathrm{OP}}}{R_{\mathrm{ON}}}$.

The Redfield's concept therefore asserts the existence of coefficients $R_{\mathrm{ON}}, R_{\mathrm{OP}}$, and $R_{\mathrm{NP}}$ which are constant, both with time and with space.

Determining the values of these coefficients is of great interest, especially nowadays. 5 These coefficients are involved not only in the nutrients cycle but also in the carbon cycle (Goyet and Brewer, 1993; Roy-Barman and Jeandel, 2011). On the ocean surface, the atmospheric carbon dioxide dissolves in seawater; in surface waters, photosynthesis consumes carbon dioxide and transforms it into organic carbon; carbon is released into deeper waters by the oxidation of organic matter. This is the biological carbon 10 "pump".

Actually, human activities cause a dramatic increase of carbon dioxide into the atmosphere. So the ocean absorbs more and more carbon dioxide, which brings about unprecedented changes in ocean biogeochemical processes and in marine ecosystems. To know how the biological activity continues to drive the carbon dioxide, de15 scribed as "anthropogenic", toward the ocean interior, is crucial today (Goyet and Touratier, 2009; Touratier et al., 2012).

Typical values of the Redfield ratios are those given by Redfield et al. (1963): the stoichiometric coefficients $\psi_{\mathrm{O}_{2}}, \psi_{\mathrm{NO}_{3}^{-}}$, and $\psi_{\mathrm{PO}_{4}^{3-}}$ of Eq. (1) are equal to 138,16 and 1 respectively, and lead to $R_{\mathrm{OP}}=138, R_{\mathrm{NP}}=16$ and $R_{\mathrm{ON}}=9$ (all numerical values are 20 rounded to the unit).

Since then, numerous studies have been conducted on the subject (see Sect. 3). They all confirm the Redfield's concept, but their results may give different values: depending on the studies, from 7 to 11 for $R_{\mathrm{ON}}$, from 95 to 190 for $R_{\mathrm{OP}}$, and from 12 to 26 for $R_{\mathrm{NP}}$. Moreover, while Redfield established constant values at any point of the 25 world ocean (the oceans are in open communication with each other, and constitute the world ocean), the majority of them indicate that the Redfield ratios are variable
ESDD

6, 2383-2416, 2015

Characterization of

ocean

biogeochemical

processes

V. Guglielmi et al.

\section{Title Page}

Abstract

Introduction

Conclusions

References

Tables

Figures

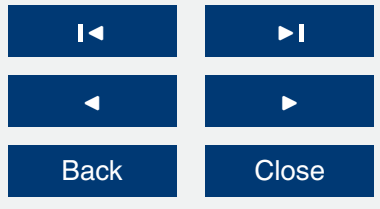

Full Screen / Esc

Printer-friendly Version

Interactive Discussion 
according to ocean basin and to depth. This variability is further linked to the role of anthropogenic carbon, which does not penetrate in the same way everywhere in the ocean.

Here, we present a new method for determining the Redfield ratios. Like most other 5 existing methods, it is based upon the inclusion of ocean circulation in addition to the composition of seawater. Its main interest is to be theoretically applicable everywhere (subject to the availability of sufficient independent data) while the other methods are in essence limited to particular zones.

\section{Seawater composition}

\subsection{Hydrology}

The two main characteristics of a seawater sample, in addition of its geographical position and its pressure (which is directly related to the depth at which it was taken), are its temperature and salinity. Seawater contains dissolved salts, in the form of ions (the main ones being the following six: $\left.\mathrm{Cl}^{-}, \mathrm{Na}^{+}, \mathrm{K}^{+}, \mathrm{Ca}^{2+}, \mathrm{Mg}^{2+}, \mathrm{SO}_{4}^{2-}\right)$. Salinity measures 15 the amount of ions present in a kilogram of seawater.

Salinity of a seawater sample is determined by measuring its electrical conductivity compared to that of a solution of known salinity. Thus, since salinity is a ratio of conductivity, salinity is dimensionless.

\subsection{Water masses}

20 Under an appearance of stability, the ocean is in perpetual motion. Ocean circulation is mainly due to the exchanges of heat and gases with the atmosphere, and to the rotation of the Earth.

A "water mass" is a volume of water whose elements have the same history, i.e. have been formed in the same way in the same place (Tomczak, 1999). A water mass
ESDD

6, 2383-2416, 2015

Characterization of

ocean

biogeochemical

processes

V. Guglielmi et al.

\section{Title Page}

Abstract Introduction

Conclusions

References

Tables

Figures

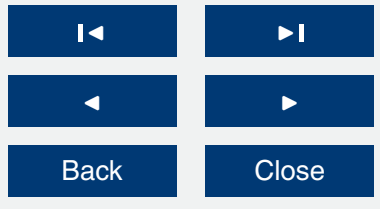

Full Screen / Esc

Printer-friendly Version

Interactive Discussion 
acquires its characteristics of temperature and salinity at surface, as a result of exchanges with the atmosphere, in well-defined water mass formation sites. Then, the water becomes heavier, it plunges and moves along surfaces of equal density.

As soon as the water mass has left the surface, its temperature and salinity can no 5 longer change because there is no more exchange with the atmosphere: thus, they are called "conservative tracers". They represent the signature of the water mass.

Along its journey, a water mass meets other water masses, with which it mixes. Thus, the features of the "conservative tracers" (temperature and salinity) in seawater vary from one ocean (geographical or depth) area to another due to the mixing of water 10 masses.

Consider an area of the ocean where $N$ water masses are present. In this area, any seawater sample results from the mixing of these water masses, in the proportions $k_{1}, k_{2}, \ldots, k_{N}$ called mixing coefficients. These coefficients satisfy:

$\forall i \in\{1,2, \ldots, N\}, 0 \leq k_{i} \leq 1$

15 and:

$\sum_{i=1}^{N} k_{i}=1$.

Any conservative characteristic $C$ of a given sample verifies:

$C=\sum_{i=1}^{N} k_{i} C_{i}$

where $C_{i}$ is the characteristic of the water mass $i$. The value of $C$ depends only upon
ESDD

6, 2383-2416, 2015

Characterization of

ocean

biogeochemical

processes

V. Guglielmi et al.

Title Page

Abstract

Introduction

Conclusions

References

Tables

Figures

14

$>$ I

4

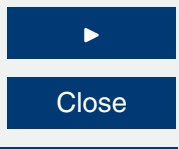

Full Screen / Esc

Printer-friendly Version

Interactive Discussion 


\subsection{Conservative tracers}

There are other conservative tracers than temperature and salinity. Some are natural (like some radioactive elements due to cosmic rays), and some are artificial (such as CFCs, chlorofluorocarbons, which were manufactured and introduced into 5 the atmosphere by Man).

Since their concentrations vary according to biological activity (as mentioned in Sect. 1), oxygen, nitrate and phosphate are not considered as conservative tracers. Their concentrations can be decomposed as the sum of a term reflecting the conservative mixing of water masses in the current sample, and a second term reflecting local 10 biochemical processes:

$$
\begin{aligned}
& {\left[\mathrm{O}_{2}\right]=\sum_{i=1}^{N} k_{i}\left[\mathrm{O}_{2}\right]_{i}-\Delta \mathrm{O}_{2}} \\
& {\left[\mathrm{NO}_{3}^{-}\right]=\sum_{i=1}^{N} k_{i}\left[\mathrm{NO}_{3}^{-}\right]_{i}+\Delta \mathrm{NO}_{3}^{-}} \\
& {\left[\mathrm{PO}_{4}^{3-}\right]=\sum_{i=1}^{N} k_{i}\left[\mathrm{PO}_{4}^{3-}\right]_{i}+\Delta \mathrm{PO}_{4}^{3-}}
\end{aligned}
$$

$\left[\mathrm{O}_{2}\right],\left[\mathrm{NO}_{3}^{-}\right]$and $\left[\mathrm{PO}_{4}^{3-}\right]$ are the sample concentrations (in $\mu \mathrm{molkg}^{-1}$ ) of oxygen, ni15 trate, and phosphate, respectively. $\left[\mathrm{O}_{2}\right]_{i},\left[\mathrm{NO}_{3}^{-}\right]_{i}$ and $\left[\mathrm{PO}_{4}^{3-}\right]_{i}$ are the concentrations of the water mass $i$. The minus sign in Eq. (8) reminds that the oxygen is consumed when nitrate and phosphate are produced.

\section{ESDD}

6, 2383-2416, 2015

Characterization of

ocean

biogeochemical

processes

V. Guglielmi et al.

\section{Title Page}

\section{Abstract}

Introduction

Conclusions

References

Tables

Figures

\section{4}

4

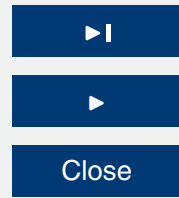

Full Screen / Esc

Printer-friendly Version

Interactive Discussion 
The Redfield's principle of variations in constant proportions, allows the construction of the tracers NO and PO (Broecker, 1974):

$\mathrm{NO}=\left[\mathrm{O}_{2}\right]+R_{\mathrm{ON}}\left[\mathrm{NO}_{3}^{-}\right]$

$\mathrm{PO}=\left[\mathrm{O}_{2}\right]+R_{\mathrm{OP}}\left[\mathrm{PO}_{4}^{3-}\right]$.

$5 \mathrm{NO}$ and PO are called "composite tracers" (each consisting of two non-conservative characteristics), and they are themselves conservative. Indeed, we get, by combining Eqs. (8), (9) and (11):

$$
\begin{aligned}
\mathrm{NO} & =\sum_{i=1}^{N} k_{i}\left[\mathrm{O}_{2}\right]_{i}-\Delta \mathrm{O}_{2}+R_{\mathrm{ON}}\left(\sum_{i=1}^{N} k_{i}\left[\mathrm{NO}_{3}^{-}\right]_{i}+\Delta \mathrm{NO}_{3}^{-}\right) \\
& =\sum_{i=1}^{N} k_{i}\left(\left[\mathrm{O}_{2}\right]_{i}+R_{\mathrm{ON}}\left[\mathrm{NO}_{3}^{-}\right]_{i}\right)-\Delta \mathrm{O}_{2}+R_{\mathrm{ON}} \Delta \mathrm{NO}_{3}^{-} .
\end{aligned}
$$

10 The concentrations variations respect: $\Delta \mathrm{O}_{2}=R_{\mathrm{ON}} \Delta \mathrm{NO}_{3}^{-}$(cf. Eq. 2), so:

$\mathrm{NO}=\sum_{i=1}^{N} k_{i}\left(\left[\mathrm{O}_{2}\right]_{i}+R_{\mathrm{ON}}\left[\mathrm{NO}_{3}^{-}\right]_{i}\right)$.

By defining the characteristic $\mathrm{NO}_{i}$ of the water mass:

$\mathrm{NO}_{i}=\left[\mathrm{O}_{2}\right]_{i}+R_{\mathrm{ON}}\left[\mathrm{NO}_{3}^{-}\right]_{i}$.

one finds again an equation (see Eq. 7) of a conservative tracer:

$15 \mathrm{NO}=\sum_{i=1}^{N} k_{i} \mathrm{NO}_{i}$.

Thus, NO (and similarly PO) depends only upon the mixing of water masses at the considered point.
ESDD

6, 2383-2416, 2015

Characterization of

ocean

biogeochemical

processes

V. Guglielmi et al.

Title Page

Abstract

Introduction

Conclusions

References

Tables

Figures

14

4

Back

Full Screen / Esc

Printer-friendly Version

Interactive Discussion 


\section{Theory}

In order to determine the values of the Redfield ratios, existing methods generally seek to determine the non-conservative fractions $\Delta \mathrm{O}_{2}, \Delta \mathrm{NO}_{3}^{-}$and $\Delta \mathrm{PO}_{4}^{3-}$ of Eqs. (8)-(10). These fractions are proportional, and the proportionality coefficients directly produce 5 the Redfield ratios.

A first category of methods (Alvarez-Borrego et al., 1975; Castro et al., 1998; Hupe and Karstensen, 2000; Schneider et al., 2005) begin to determine, for a given area, the various water masses in presence and their characteristics: $\left[\mathrm{O}_{2}\right]_{i},\left[\mathrm{NO}_{3}^{-}\right]_{i}$ and $\left[\mathrm{PO}_{4}^{3-}\right]_{i}$. Then, for each sample, the mixing coefficients $k_{i}$ must be calculated. They allow to de-

10 termine the conservative parts of the oxygen and nutrient concentrations: $\sum_{i=1}^{N} k_{i}\left[\mathrm{O}_{2}\right]_{i}$, $\sum_{i=1}^{N} k_{i}\left[\mathrm{NO}_{3}^{-}\right]_{i}$ and $\sum_{i=1}^{N} k_{i}\left[\mathrm{PO}_{4}^{3-}\right]_{i}$. To access to the non-conservative fractions, then just subtract these conservative parts to the corresponding measured concentrations $\left[\mathrm{O}_{2}\right]$, $\left[\mathrm{NO}_{3}^{-}\right]$and $\left[\mathrm{PO}_{4}^{3-}\right]$. The disadvantage of these methods lies in the errors in the estimation of the mixing coefficients. First, the characteristics of a water mass can never be determined exactly. Then, the mixing coefficients can be calculated only sample by sample, without the possibility to reduce errors by using a global calculation on all samples.

A second category of methods does not explicitly determine the mixing coefficients. From assumptions upon the various water masses in the vicinity, they build rela20 tionships (other than simple proportionality) between concentrations $\left[\mathrm{O}_{2}\right],\left[\mathrm{NO}_{3}^{-}\right]$and $\left[\mathrm{PO}_{4}^{3-}\right]$. The identification of the parameters of these relationships leads to the Redfield ratios. But these methods are only applicable either to specific areas (Takahashi et al., 1985; Minster and Boulahdid, 1987; Shaffer et al., 1999; Li and Peng, 2002; Schroeder et al., 2010), or to areas where at the most two water masses mix (Anderson and Sarmiento, 1994; Placenti et al., 2013).

ESDD

6, 2383-2416, 2015

Characterization of

ocean

biogeochemical

processes

V. Guglielmi et al.

\section{Title Page}

Abstract Introduction

Conclusions References

Tables Figures

14

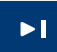

4

Back

Full Screen / Esc

Printer-friendly Version

Interactive Discussion 
The advantage of the method presented here, is that first, it does not require the identification of characteristics of each water mass, nor any knowledge about the mixing coefficients. Thus, it eliminates a primary source of errors. Secondly, if there are enough data available, it can be applied everywhere, whatever the area, and its application is 5 always done in the same way.

\subsection{Assumptions and notations}

Let us consider $P$ samples of seawater, spread in an area of the world ocean where $N$ water masses (known also as "sources") are present. We suppose that for each sample, we have measurements of $M$ conservative tracers with $P \geq M$.
$\mathbf{D}=\left(\begin{array}{cccc}\vdots & & & \vdots \\ d_{l, 1} & d_{l, 2} & \cdots & d_{l, M} \\ \vdots & & & \vdots\end{array}\right)$

For each measurement point $I, 1 \leq I \leq P$, the corresponding values $d_{l, 1}, d_{l, 2}, \ldots, d_{l, M}$ of the $M$ conservative tracers are in row $/$. For example, the first column of the matrix D can be composed of temperature data, and the second column of salinity data.

$$
\mathbf{1}_{P}=\left(\begin{array}{c}
1 \\
\vdots \\
1
\end{array}\right)
$$

The starting point of our method is based on the following question:

\section{ESDD}

\section{6, 2383-2416, 2015}

\section{Characterization of ocean \\ biogeochemical processes}

V. Guglielmi et al.

\section{Title Page}

Abstract Introduction

Conclusions References

Tables Figures

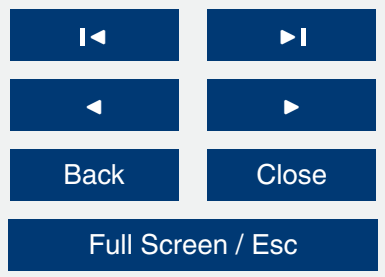

Printer-friendly Version

Interactive Discussion 
Is there a vector $\boldsymbol{a}$ of $M$ real coordinates, $\boldsymbol{a}=\left(\begin{array}{c}a_{1} \\ a_{2} \\ \vdots \\ a_{M}\end{array}\right)$, such that

ESDD

$\mathrm{D} a=1_{P} ?$

Let $\mathbf{K}$ be the matrix ( $P$ rows $\times N$ columns) of mixing coefficients:

$\mathbf{K}=\left(\begin{array}{cccc}\vdots & & & \vdots \\ k_{l, 1} & k_{l, 2} & \cdots & k_{l, N} \\ \vdots & & & \vdots\end{array}\right)$.

5 For each sample $I, 1 \leq l \leq P$, the corresponding mixing coefficients $k_{l, 1}, k_{l, 2}, \ldots, k_{l, N}$ are in row $/$. Their sum being equal to 1 (cf. Eq. 6), we have:

$\mathbf{K} \mathbf{1}_{N}=\mathbf{1}_{P}$

where $\mathbf{1}_{N}$ is the vector of $N$ rows $\times 1$ column, whose all elements equal 1 .

Let $\mathbf{W}$ be the matrix ( $N$ rows $\times M$ columns) of the characteristics of sources:

${ }_{10} \quad \mathbf{W}=\left(\begin{array}{cccc}\vdots & & & \vdots \\ w_{l, 1} & w_{l, 2} & \cdots & w_{l, M} \\ \vdots & & & \vdots\end{array}\right)$

For each water mass $l, 1 \leq l \leq N$, the corresponding conservative tracers $w_{l, 1}, w_{l, 2}, \ldots, w_{l, M}$ are in row $l$. As all considered tracers are conservative, Eq. (7) becomes, in matrix form:

$\mathrm{D}=\mathrm{KW}$.

15 It is necessary to define $\mathbf{K}$ and $\mathbf{W}$ to demonstrate that the vector $\mathbf{a}$ exists, but it is not necessary to know their values to apply our method (and this is the main advantage of this method).

Characterization of

ocean

biogeochemical

processes

V. Guglielmi et al.

Title Page

Abstract

Introduction

Conclusions

References

Tables

Figures

14

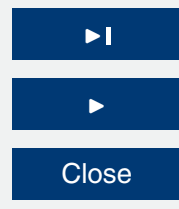

Back

Close

Full Screen / Esc

Printer-friendly Version

Interactive Discussion 


\subsection{Existence of a linear relation between conservative tracers}

Let us concentrate here to solve Eq. (20). In other words, do $M$ conservative tracers make an hyperplane in $R^{M}$ ?

Furthermore, suppose that the $N$ sources are independent (none is the result of 5 a mixing of the others). In practice, it is mainly the knowledge of the hydrology of the ocean area which ensures correct identification of the independent water masses. Thus, the rank of the matrix $\mathbf{D}$ is equal to the minimum of $N$ and $M$. Three cases are possible (referring to the results on the resolution of a linear system):

- Case 1: $N>M$ (more water masses than conservative tracers) Then, the rank of matrix $\mathbf{D}$ is equal to $M$. So we know that the only possible solution of the equation $\mathbf{D a}=\mathbf{1}_{P}$ is the solution in the least-squares sense:

$$
\boldsymbol{a}_{m c}=\left(\mathbf{D}^{\prime} \mathbf{D}\right)^{-1} \mathbf{D}^{\prime} \mathbf{1}_{P}
$$

where the apostrophe operator ( $I$ ) stands for the transpose matrix.

The vector $\boldsymbol{a}_{m c}$ minimizes the norm of the residuals of the equation $\mathbf{D} \boldsymbol{a}=\mathbf{1}_{p}$, but there is no guarantee that this minimum is equal to zero, or in other words that $\boldsymbol{a}_{m c}$ is a exact solution of the equation. Moreover, in general, it is not! So in this case, there is a priori no hyperplane of the tracers.

- Case 2: $N<M$ (less water masses than conservative tracers)

Then, the rank of $\mathbf{D}$ is equal to $N$. So we know nothing about $\mathbf{D} \boldsymbol{a}=\mathbf{1}_{P}$.

Consider the same equation, not anymore on data but on sources:

$\mathrm{W} a=\mathbf{1}_{N}$.

The rank of matrix $\mathbf{W}$ is equal to $N$. So Eq. (26) has at least one (exact) solution, the vector

$a_{S}=\mathbf{W}^{\prime}\left(\mathbf{W} \mathbf{W}^{\prime}\right)^{-1} \mathbf{1}_{N}$.

ESDD

6, 2383-2416, 2015

Characterization of

ocean

biogeochemical

processes

V. Guglielmi et al.

Title Page

Abstract

Introduction

Conclusions References

Tables

Figures

14

$>$ I

4

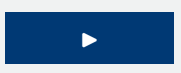

Back

Close

Full Screen / Esc

Printer-friendly Version

Interactive Discussion 
(There is no guarantee that this solution is unique, but this is not a problem for our final objective.)

This solution satisfies:

$\mathbf{W} \boldsymbol{a}_{S}=\mathbf{1}_{N}$

$\mathrm{KW} \boldsymbol{a}_{S}=\mathrm{K} \mathbf{1}_{N}$

$\mathrm{KW} \boldsymbol{a}_{s}=\mathbf{1}_{P}$

and finally, with Eq. (24):

$\mathrm{D} a_{s}=1_{P}$.

In other words, $\boldsymbol{a}_{s}$ is also a solution of the first equation on data (Eq. 20). So in this case, the tracers form at least one hyperplane.

- Case 3: $N=M$ (as many water masses as conservative tracers) This case falls in both the second case (rank of $\mathbf{D}$ equal to $N$ ) and in the first case (rank of $\mathbf{D}$ equal to $M$ ). The equation $\mathbf{D} a=\mathbf{1}_{P}$ therefore has a unique solution, which is:

$a_{S}=\left(D^{\prime} \mathbf{D}\right)^{-1} \mathbf{D}^{\prime} \mathbf{1}_{P}$.

Or equivalently, since here $\mathbf{W}$ is invertible:

$\boldsymbol{a}_{S}=\mathbf{W}^{-1} \mathbf{1}_{N}$.

In conclusion, if $N \leq M$ (as many or more conservative tracers than water masses), we know that there exists a linear relation between the $M$ conservative tracers.
ESDD

6, 2383-2416, 2015

Characterization of

ocean

biogeochemical

processes

V. Guglielmi et al.

Title Page

Abstract

Introduction

Conclusions

References

Tables

Figures

14

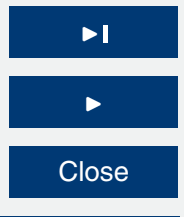

Full Screen / Esc

Printer-friendly Version

Interactive Discussion 
We will see in Sect. 4 how to find the coefficients of this relation, using an algorithm of total least-squares (Markovsky and Van Huffel, 2007). For now, we have demonstrated the existence of a relation, but we have no means of getting it. If $N<M$, the vector $\boldsymbol{a}_{s}=$ $\mathbf{W}^{\prime}\left(\mathbf{W} \mathbf{W}^{\prime}\right)^{-1} \mathbf{1}_{N}$ (cf. Eq. 27) is incalculable since the matrix $\mathbf{W}$ is unknown. If $N=M$, the 5 Eq. (33) fails to provide the solution (since $\mathbf{W}$ is still unknown) and the Eq. (32) cannot be applied directly. Indeed, the computation of the pseudoinverse (matrix $\left(\mathbf{D}^{\prime} \mathbf{D}\right)^{-1} \mathbf{D}^{\prime}$ ) of the matrix $\mathbf{D}$ is so sensitive to the unavoidable noise (of the measured data) that it often leads to unusable results.

\subsection{Principle of the determination of the Redfield ratios}

10 Let us now assuming $N \leq M$. This restricts the use of our method to areas where sufficient measurement data are available compared to the water masses involved.

How the existence of a linear relation between the conservative tracers permits to determine the Redfield ratios? Just take, among the tracers, the composite tracers NO or PO. We now know that there exists a linear relation between these composite tracers and the other considered tracers. The estimate of this linear relationship, which has the minimum error, will correspond to the correct value of the coefficients $R_{\mathrm{ON}}$ or $R_{\mathrm{OP}}$ (in the calculation of $\mathrm{NO}$ or $\mathrm{PO}$ ).

For example, consider an area where we have at our disposal data of temperature $T$, salinity $S$, oxygen $\left[\mathrm{O}_{2}\right]$ and nitrate $\left[\mathrm{NO}_{3}^{-}\right]$, and where there are at maximum three water 20 masses. The tracer NO is given by Eq. (11), in which the value of $R_{\mathrm{ON}}$ is the unknown to be determined. From now on, we know that there exist $a_{1}, a_{2}, a_{3}$ in $R$ such that, when the value taken for $R_{\mathrm{ON}}$ is the correct one, the data of every sample in the area satisfy the equation:

$a_{1} T+a_{2} S+a_{3} \mathrm{NO}=1$.

25 The correct value of $R_{\mathrm{ON}}$ is that minimizing the error of reconstruction of Eq. (34).
ESDD

6, 2383-2416, 2015

Characterization of

ocean

biogeochemical

processes

V. Guglielmi et al.

Title Page

Abstract

Conclusions

Tables

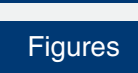

14

4

4

Back

Introduction

References

Figures

Full Screen / Esc

Printer-friendly Version

Interactive Discussion 
Note that we can write Eq. (34) in the form:

ESDD

6, 2383-2416, 2015

Hence, if we set

$a_{4}=a_{3} R_{\mathrm{ON}}$

5 we have:

$a_{1} T+a_{2} S+a_{3}\left[\mathrm{O}_{2}\right]+a_{4}\left[\mathrm{NO}_{3}^{-}\right]=1$.

Thus, we can also determine $a_{1}, a_{2}, a_{3}, a_{4}$ and then apply:

$R_{\mathrm{ON}}=\frac{a_{4}}{a_{3}}$.

\section{Data and calculation}

\subsection{Conservative tracers}

The data that we have used are those of GLODAP database (Key et al., 2004), which covers the global ocean by combining a wide set of oceanographic measurements. Measurements of different expeditions since 1990, through all oceans, were synthesized and calibrated to provide a global database. In GLODAP, there are measurements of temperature, salinity, oxygen, nitrate, and phosphate. Oxygen and nitrate lead to the conservative tracer NO while oxygen and phosphate lead to PO. Temperature and salinity are used directly as conservative tracers.

Strictly speaking, because of the slight compressibility of sea water, which causes a warming due to pressure, the temperature "in situ" (archived in GLODAP) is not exactly a conservative parameter because it varies with pressure. The laws of thermodynamics permit to calculate the temperature corrected for the pressure effect (see the 2397

\section{Characterization of ocean \\ biogeochemical processes}

V. Guglielmi et al.

Title Page

Abstract Introduction

Conclusions References

Tables Figures

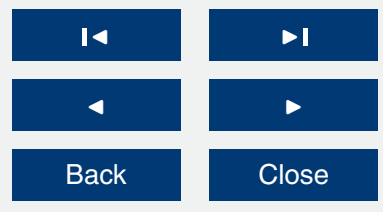

Full Screen / Esc

Printer-friendly Version

Interactive Discussion 
official site http://www.teos-10.org/ about the Thermodynamic Equation Of Seawater). It is this conservative temperature that we calculated and used. Similarly, we calculated the "preformed" salinity which is strictly conservative. It is also calculated from the measured salinity, according to the same laws of thermodynamics. It is the one we used here.

Moreover, the measurements available in GLODAP allow us to build another composite tracer: $\operatorname{TrOCA}^{0}$. It is made from temperature and total alkalinity (total alkalinity measures the excess of basic species over acid species in seawater). Its precise definition and its properties are described in Touratier and Goyet (2004) and Touratier 10 et al. (2007). Here, its interest is to be conservative.

So we have five conservative tracers: (conservative) temperature $T$, (preformed) salinity $S, N O, P O$ and $\operatorname{TrOCA}^{0}$. We recall that we have demonstrated in the preceding paragraphs, the existence of a linear relation between any set of $M$ conservative tracers, in any area comprising at maximum $M$ water masses. In addition, the fact of taking $15 \mathrm{NO}$ or PO among the $M$ tracers enables to determine the Redfield ratios: the correct values of $R_{\mathrm{ON}}$ or $R_{\mathrm{OP}}$ are those minimizing the error of reconstruction of the linear relation between tracers.

\subsection{Measurement noise}

Let us continue the example already given in Sect. 3.3 of computing $R_{\mathrm{ON}}$ in an ocean 20 area with a maximum of three water masses (in an area with four water masses, we
would use $\operatorname{TrOCA}^{0}$ in addition to temperature and salinity). In order to determine $R_{\mathrm{ON}}$, we have two possibilities. The first one, is to directly determine the four coefficients of the linear relation (Eq. 37) and then to calculate $R_{\mathrm{ON}}$ using the Eq. (38). The second one, is a minimization loop on the values of $R_{\mathrm{ON}}$ : we successively assume different we determine the three coefficients of the Eq. (34) as well as the norm of the residuals of this Eq. (34). Finally, we choose the correct value of $R_{\mathrm{ON}}$ as the one corresponding to the smallest norm of residuals.

ESDD

6, 2383-2416, 2015

Characterization of

ocean

biogeochemical

processes

V. Guglielmi et al.

\section{Title Page}

Abstract Introduction

Conclusions References

Tables

Figures

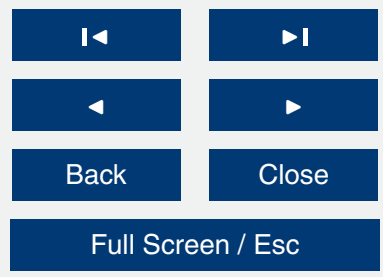

Printer-friendly Version

Interactive Discussion 
If the data were free from noise, the above two options would lead to the same result. But of course, the available data are noisy! They are supposed to be affected by additive Gaussian noise with zero mean and standard deviation depending on the data type: $0.001{ }^{\circ} \mathrm{C}$ for temperature, 0.0001 for salinity, $0.02 \mu \mathrm{mol} \mathrm{kg}^{-1}$ for nitrate, $0.005 \mu \mathrm{mol} \mathrm{kg}^{-1}$ 5 for phosphate, $2 \mu \mathrm{mol} \mathrm{kg}^{-1}$ for oxygen.

The presence of noise makes crucial the choice of the calculation method. The second of the above two possibilities is not satisfactory because it too often leads to a divergence of the minimization algorithm. Thus, we wrote our calculation program by choosing the first option, i.e. by decomposing the tracer NO to arrive at Eq. (37).

${ }_{10}$ Similarly, in order to calculate $R_{\mathrm{OP}}$, we must determine the four coefficients $b_{1}, b_{2}, b_{3}, b_{4}$ of the equation:

$b_{1} T+b_{2} S+b_{3}\left[\mathrm{O}_{2}\right]+b_{4}\left[\mathrm{PO}_{4}^{3-}\right]=1$

then calculate:

$R_{\mathrm{OP}}=\frac{b_{4}}{b_{3}}$

15 The determination of $R_{\mathrm{ON}}$ and of $R_{\mathrm{OP}}$ are thus made independently. In theory, one can imagine a simultaneous calculation of $R_{\mathrm{ON}}$ and $R_{\mathrm{OP}}$. Just construct a double minimization loop through the values of both $R_{\mathrm{ON}}$ and $R_{\mathrm{OP}}$, in order to minimize the residuals of an equation involving both the tracer $\mathrm{NO}$ and the tracer $\mathrm{PO}$ :

$\alpha_{1} T+\alpha_{2} S+\alpha_{3} \mathrm{NO}+\alpha_{4} \mathrm{PO}=1$

20 In practice, this double loop, as the previously envisaged simple loop, often diverges (here again, because of the presence of noise in the data). We therefore did not keep it as a valid algorithm.

Note that, since we cannot use both $\mathrm{NO}$ and $\mathrm{PO}$ tracers simultaneously, we are reduced to up to four conservative tracers: for the estimation of $R_{\mathrm{ON}}$, temperature, 2399
ESDD

6, 2383-2416, 2015

Characterization of

ocean

biogeochemical

processes

V. Guglielmi et al.

\section{Title Page}

Abstract

Introduction

Conclusions

References

Tables

Figures

14

4

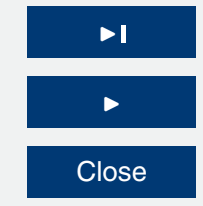

Back

Close

Full Screen / Esc

Printer-friendly Version

Interactive Discussion 
salinity, $\operatorname{TrOCA}^{0}$ and NO; for the estimation of $R_{\mathrm{OP}}$, temperature, salinity, $\operatorname{TrOCA}^{0}$ and $P O$. Consequently, we will be limited to study ocean areas with a maximum of four water masses. For most ocean areas, as shown below (for example for the Atlantic Ocean), this is just fine since we can often split a large area in smaller areas. Yet, for an ocean 5 area with more than four water masses, the calculation algorithm would remain the same but it would require additional conservative tracers (CFCs, for example).

\subsection{Estimation of the Redfield ratios}

Returning to Eq. (37), it is now necessary to estimate its coefficients, in order to then determine $R_{\mathrm{ON}}$ (with Eq. 38). In order to calculate $R_{\mathrm{OP}}$, the approach is identical, from 10 the Eq. (39) and then Eq. (40).

It is a least-squares problem, but in which the data are noisy and the noises have different standard deviations. Furthermore, in Eq. (37), the second term of equality is not zero but equal to 1 . The robust estimator is therefore the Generalized Total LeastSquares estimator (Markovsky and Van Huffel, 2007). In order to compute this estima15 tor, we should write the equation in the form:

$a_{1} T+a_{2} S+a_{3}\left[\mathrm{O}_{2}\right]+a_{4}\left[\mathrm{NO}_{3}^{-}\right]-1=0$

or:

$a_{1} T+a_{2} S+a_{4}\left[\mathrm{NO}_{3}^{-}\right]-1=-a_{3}\left[\mathrm{O}_{2}\right]$

or finally:

20 $x_{1} T+x_{2} S+x_{3}\left[\mathrm{NO}_{3}^{-}\right]+x_{4}=\left[\mathrm{O}_{2}\right]$

or, in matrix form:

$A x=b$.
ESDD

6, 2383-2416, 2015

Characterization of

ocean

biogeochemical

processes

V. Guglielmi et al.

Title Page

Abstract

Introduction

Conclusions References

Tables

Figures

14

$>$ I

4

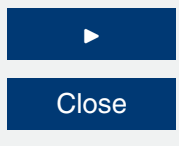

Full Screen / Esc

Printer-friendly Version

Interactive Discussion 
For every measurement point $/$, note $T_{l}, S_{l},\left[\mathrm{NO}_{3}^{-}\right]$, and $\left[\mathrm{O}_{2}\right]$, the corresponding data values. The first column of the matrix $\mathbf{A}$ contains temperature data, the second column those of salinity, the third column those of nitrate, and the fourth column consists of constant values equal to 1 :

${ }_{5} \mathbf{A}=\left(\begin{array}{cccc}\vdots & \vdots & \vdots & 1 \\ T_{l} & S_{/} & {\left[\mathrm{NO}_{3}^{-}\right],} & 1 \\ \vdots & \vdots & \vdots & 1\end{array}\right)$

The vector $\boldsymbol{b}$ contains the measurements of oxygen:

$\boldsymbol{b}=\left(\begin{array}{c}\vdots \\ {\left[\mathrm{O}_{2}\right]_{/}} \\ \vdots\end{array}\right)$

The vector

$x=\left(\begin{array}{l}x_{1} \\ x_{2} \\ x_{3} \\ x_{4}\end{array}\right)$

10 is that of the parameters to be estimated.

Equation (38), which allowed us to determine the value of $R_{\mathrm{ON}}$, becomes:

$R_{\mathrm{ON}}=-x_{3}$.

The non-zero second term of the initial Eq. (37) therefore results in a constant column in the matrix A (i.e. a column without noise). To get an estimate as robust as possible, 15 the vector $\boldsymbol{b}$ must contain the noisiest data (oxygen).

ESDD

6, 2383-2416, 2015

Characterization of ocean

biogeochemical processes

V. Guglielmi et al.

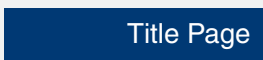

Abstract

Introduction

Conclusions

References

Tables

Figures

14

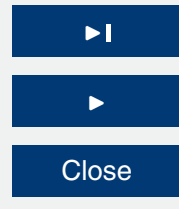

Back

Close

Full Screen / Esc

Printer-friendly Version

Interactive Discussion 
Furthermore, our problem is an "ill-posed" inverse problem: the matrix containing all the measurement data is ill-conditioned, due to both the additive noise and the significant differences in the orders of magnitude among the tracers. This bad conditioning prohibits any direct pseudoinverse solution. On the contrary, in order to "regu5 larize" the problem, the estimation algorithm suggests truncation, if necessary, of the lowest eigenvalues of this matrix.

Provided that a solution exists, the method of Generalized Total Least-Squares gives an analytical formulation of the result, which is much more reliable than a result that would have been found by a local optimization. Hence it was very important to first 10 demonstrate that a solution exists.

Finally, let us note that among the measurement points, there are always a few of them that are aberrant (at these points, the measurements were, for various reasons, totally biased and flawed). To overcome this issue, we iteratively calculate the estimate: on every iteration, we remove the data points that are three times above the standard 15 deviation of the residuals of the estimation.

We wrote the estimation algorithm using MATLAB.

\section{Results and discussion}

\subsection{Study areas}

\subsubsection{The Atlantic Ocean}

20 We chose to test this method in the Atlantic Ocean because it is a key element in the large-scale circulation of the global ocean. That's basically it which connects the two polar oceans (the Antarctic and Arctic Oceans). The exchanges between the Arctic Ocean and the Pacific Ocean are limited to the Bering Strait, while on the contrary, the Arctic Ocean is open onto the Atlantic Ocean by the Nordic Seas (the Norwegian Sea,

\section{ESDD}

6, 2383-2416, 2015

Characterization of

ocean

biogeochemical

processes

V. Guglielmi et al.

\section{Title Page}

Abstract

Introduction

Conclusions

References

Tables

Figures

\section{4}

4

Back

Full Screen / Esc

Printer-friendly Version

Interactive Discussion 
the Greenland Sea and the Iceland Sea). The Atlantic Ocean is thus a privileged place of transformation of surface waters into deepwater.

North of the Atlantic Ocean, under the effects of cooling and evaporation, surface waters of the Nordic Seas become denser and plunge, creating the North Atlantic Deep 5 Water, or NADW. The NADW flows at deep southward, following the American continent, and joins the deep circumpolar circulation that transports the cold and dense waters formed along the Antarctic continent. These waters mix to form the AntArctic Bottom Water, or AABW, and feed the Indian and Pacific Oceans, where they slowly rise to the surface while warming up. Then, these warmer surface waters join the North 10 Atlantic Ocean, and the process starts again (the time required for a water particle to perform this cycle is about a thousand years).

Since the method presented here needs not to have more water masses than conservative tracers, it requires to "cut" the Atlantic Ocean in several zones.

In an area where there are $N$ sources and where $M$ tracers are available, the $M$ 15 values of these tracers, for each measurement point, are the coordinates of the faces of a convex polyhedron of dimension $M$, with $N$ vertices. The projection of this polyhedron on a plane (formed for example by the temperature and salinity tracers, which gives the "diagram T-S"), is a polygon having $X$ vertices, with $X \leq N$, each vertex of the polygon corresponding to one of the sources. Such projection is often used to determine the number and position of the sources involved, by identifying the vertices of the polygon. But the determination of the vertices of the polygon has variable accuracy, depending upon the respective positions of the available measurement points. Moreover, as there is no guarantee that $X$ equals $N,(N-X)$ sources are absolutely inaccessible.

Consequently, a zoning based solely on the measurement points would be absurd. 25 Here, we identified 16 areas in the Atlantic Ocean, based not only upon the available data (via the T-S diagram), but also mainly on the current knowledge of the water masses and their movements (Fieux, 2010).
ESDD

6, 2383-2416, 2015

Characterization of

ocean

biogeochemical

processes

V. Guglielmi et al.

Title Page

Abstract Introduction

Conclusions References

Tables

Figures

14

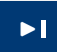

4

Back

Full Screen / Esc

Printer-friendly Version

Interactive Discussion 


\subsubsection{Latitudes}

The longitudinal limits of the Atlantic Ocean are the natural continental limits. The Atlantic Ocean is limited to the west by the American coasts and to the east by the European and African coasts. The hydrological characteristics of the Atlantic Ocean 5 allow to divide it into four latitudinal zones, as shown in Fig. 1 and defined as follows:

- The North Atlantic Ocean, at latitudes ranging from $60^{\circ} \mathrm{N}$ to $20^{\circ} \mathrm{N}$ (in red in Fig. 1). Beyond $60^{\circ} \mathrm{N}$, there is the Arctic Ocean.

- The northern Equatorial Atlantic Ocean, at latitudes ranging from $20^{\circ} \mathrm{N}$ to $5^{\circ} \mathrm{N}$ (in yellow in Fig. 1).

- The southern Equatorial Atlantic Ocean, at latitudes ranging from $5^{\circ} \mathrm{N}$ to $20^{\circ} \mathrm{S}$ (in pink in Fig. 1). This part includes the equator and its specific oceanic movements.

- The South Atlantic Ocean, at latitudes ranging from $20^{\circ} \mathrm{S}$ to $45^{\circ} \mathrm{S}$ (in green in Fig. 1). The limit of $45^{\circ} \mathrm{S}$ is determined between the Subtropical Front (a "Front" is a place of convergence of different water masses) and the Polar Front. South of the Polar Front, there is the Antarctic Ocean, where ocean circulation is very different.

\subsubsection{Depths}

At these latitudinal zones, one should add depth ranges. First, recall that we must consider only the data from below the mixed layer (cf. Sect. 1). For this, we used the database NDP-076 (Goyet et al., 2000), which gives the maximum depth of the mixed layer, for each month of the year, at any point of the world ocean (on a grid of $1^{\circ}$ longitude by $1^{\circ}$ latitude). Then, the characteristics of ocean circulation can distinguish three layers:

- the surface ocean, at depths ranging from $50 \mathrm{~m}$ down to $500 \mathrm{~m}$;

ESDD

6, 2383-2416, 2015

Characterization of

ocean

biogeochemical

processes

V. Guglielmi et al.

Title Page

Abstract

Introduction

Conclusions References

Tables

Figures

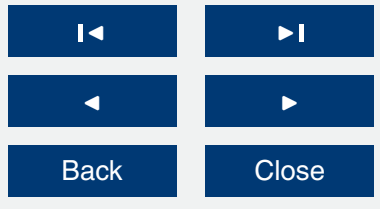

Full Screen / Esc

Printer-friendly Version

Interactive Discussion 
- the intermediate layer, at depths between 500 and 1750 m;

- the deep ocean, at depths deeper than $1750 \mathrm{~m}$.

ESDD

6, 2383-2416, 2015

\subsubsection{Mid-Atlantic Ridge}

In the deep ocean, an additional split is necessary. Indeed, the Mid-Atlantic Ridge 5 (underwater mountain range), whose depth is on average $2000 \mathrm{~m}$, splits the Western basins from the Eastern basins, and separates the flow of bottom waters. This ridge, which follows approximately the shape of continents, appears light blue in Fig. 1. For layers deeper than $1750 \mathrm{~m}$, it is thus necessary to separate the area to the west of the ridge from the area to the east. This split is made following the ridge (not according to 10 an arbitrarily longitude).

In the end, this makes 16 zones, as specified in Table 1. In each zone, there are three or four independent water masses, also indicated in Table 1. For areas with three sources, the calculation of the Redfield ratios is based upon three tracers: temperature, salinity, and either $\mathrm{NO}$ or $\mathrm{PO}$. For areas with four sources, we use the three latter tracers to which we add the tracer $\operatorname{TrOCA}^{0}$.

\subsection{Water masses}

We remind here the interest of our method: it does not require determination of the characteristics of the water sources involved. It is enough to know the number of them (in order to adjust accordingly the number of conservative tracers used in the calculation, and thus, to ensure the existence of a solution to the algorithm).

A water mass can, of course, be present in several study areas. So, some different study areas appear (cf. Table 1) as consisting of the same sources. However, it does not make sense to merge those areas when calculating the Redfield ratios. Merging them could certainly lead to numerical results, but these results would be meaningless. Indeed, for each area, we have identified the major water masses involved, those mainly responsible for the characteristics of the water in this ocean area. But each area

\section{Characterization of \\ ocean \\ biogeochemical \\ processes}

V. Guglielmi et al.

Title Page

Abstract

Introduction

Conclusions

References

Tables

Figures

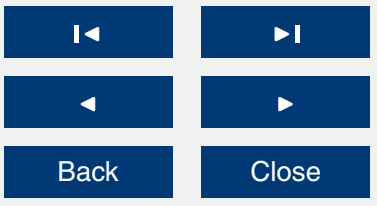

Full Screen / Esc

Printer-friendly Version

Interactive Discussion 
is also subject to the influence of other sources of less importance, and of more or less distant origin. Neglecting these other sources when estimating the Redfield ratios is possible only if the choice of the measurement points considered for an estimate, and therefore the definition of study areas, remain based on previous knowledge of ocean 5 movements.

Two deep water masses are present at all latitudes of the Atlantic Ocean: the AntArctic Bottom Water (AABW) and the North Atlantic Deep Water (NADW). The AABW is the deepest water mass: it lies over the entire bottom of the Atlantic Ocean, below $4000 \mathrm{~m}$. The NADW has its origin in the Nordic Seas and flows southward along the 10 American continent. It is present in all deep layers except in the northeast. It can be divided into three sources: the upper NADW at depths between 1200 and $1900 \mathrm{~m}$, the central NADW between 1900 and $3500 \mathrm{~m}$, the lower NADW between 3500 and $3900 \mathrm{~m}$.

Another water mass, less deep, can also be found at almost at all latitudes: the AntArtic Intermediate Water (AAIW). It originates from the Antarctic Ocean, and flows 15 northward to a maximum latitude of about $20^{\circ} \mathrm{N}$. Its presence is less strong in the east than in the west. With an average depth of $1000 \mathrm{~m}$, it influences the intermediate layer (between 500 and $1750 \mathrm{~m}$ ) but also the deep layer (beyond $1750 \mathrm{~m}$ ).

The Central or Subtropical waters are water masses with a more limited geographical spread, and a relatively shallow depth range (average depth between 500 and $700 \mathrm{~m}$ ). 20 They are formed in convergence zones, where waters tend to dive due to wind forcing. The North Atlantic SubTropical Water (NASTW) and the North Atlantic Central Water (NACW) are created north of the equator while the South Atlantic SubTropical Water (SASTW) and the South Atlantic Central Water (SACW) are created south of the equator. Note than the NACW is subjected to intense winter cooling, causing a convection 25 (vertical mixing) significantly deeper than in southern Atlantic Ocean, and hence it can mix with water from the bottom layer.

In addition to these main water masses, there are water masses of local influence. Among them, two are deep sources: in the northwest, there is the Denmark Strait Overflow Water (DSOW), at depths between 3000 and $3500 \mathrm{~m}$; in the northeast, there
ESDD

6, 2383-2416, 2015

Characterization of

ocean

biogeochemical

processes

V. Guglielmi et al.

Title Page

Abstract

Introduction

Conclusions References

Tables

Figures

14

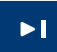

4

Back

Full Screen / Esc

Printer-friendly Version

Interactive Discussion 
is the Iceland-Scotland Overflow Water (ISOW), at depths between 2000 and $2500 \mathrm{~m}$. An intermediate water mass, the Mediterranean Water (MW), enters the Atlantic Ocean through the Strait of Gibraltar, in the northeast, and stabilizes at an average depth of $1000 \mathrm{~m}$. In the surface layer, local sources have characteristics directly related to 5 the various exchanges of heat and water with the atmosphere, and they are therefore relatively variable. These sources have no specific name. We have found a different local source in each surface zone.

\subsection{Redfield ratios}

Table 2 shows the results obtained for each zone. We estimated $R_{\mathrm{ON}}$ and $R_{\mathrm{OP}}$ inde10 pendently, using $\mathrm{NO}$ for the calculation of $R_{\mathrm{ON}}$ and using PO for the calculation of $R_{\mathrm{OP}}$ (cf. Sect. 4.3).

In order to determine the accuracy of these results, a first measurement, statistical, is given by the coefficient of determination $r^{2}$. This coefficient measures the validity of the result vector $\boldsymbol{x}$ found for Eq. (45) (it measures how successful the result $\boldsymbol{x}$ is in 15 explaining the variation of the data). $r^{2}$ can take on any value between 0 and 1 , with a value closer to 1 indicating a greater goodness of fit. For the 16 areas considered here, whether it is calculation of $R_{\mathrm{ON}}$ or calculation of $R_{\mathrm{OP}}, r^{2}$ always remains above 0.84 , and equals on average 0.94 .

A second measurement, probabilistic, is given by the standard deviation of the estimated $R_{\mathrm{ON}}$ or $R_{\mathrm{OP}}$ ratios. By analogy with the formula for the standard deviation of the Least-Squares estimator (Markovsky and Van Huffel, 2007), we determined a standard deviation equal at maximum to 0.125 for $R_{\mathrm{ON}}$ and to 2.73 for $R_{\mathrm{OP}}$ (or approximately $2 \%$ of the result). These values allowed to determine the $99 \%$ confidence interval of the results: \pm 0.3 for $R_{\mathrm{ON}}$ values and \pm 6 for $R_{\mathrm{OP}}$ values.

25 Table 2 also indicates values of the $R_{\mathrm{NP}}$ ratio. This $R_{\mathrm{NP}}$ ratio is not estimated directly from the data, but it is deducted from the results obtained for the first two ratios (according to Eq. 4: $R_{\mathrm{NP}}=R_{\mathrm{OP}} / R_{\mathrm{ON}}$ ).
ESDD

6, 2383-2416, 2015

Characterization of

ocean

biogeochemical

processes

V. Guglielmi et al.

Title Page

Abstract

Introduction

Conclusions References

Tables

Figures

14

4

Back

Full Screen / Esc

Printer-friendly Version

Interactive Discussion 
Overall, the first striking result is that the values obtained for the ratios, are remarkably near-constant! They vary relatively little from one zone to another, which is in good agreement with the existence of the Redfield's concept.

Furthermore, our results are very close to those first given by Redfield himself in 51963 (Redfield et al., 1963). Nevertheless, the values here are in general, slightly lower than those estimated by Redfield $\left(R_{\mathrm{ON}}=9\right.$ and $\left.R_{\mathrm{OP}}=138\right)$. However, in view of our method (selection of study areas according to the hydrological characteristics and then use of an identical estimator whatever the area), the variations in these values from one area to another are certainly more significant than the values themselves.

10 We detect significant variations both in latitude and in depth. From north to south (from $60^{\circ} \mathrm{N}$ to $45^{\circ} \mathrm{S}$ ), regardless of depth, $R_{\mathrm{ON}}$ decreases and then increases, $R_{\mathrm{OP}}$ increases and then decreases, and therefore $R_{\mathrm{NP}}\left(R_{\mathrm{NP}}=\frac{R_{\mathrm{OP}}}{R_{\mathrm{ON}}}\right)$ increases and then decreases. When the depth increases, regardless of latitude, both $R_{\mathrm{ON}}$ and $R_{\mathrm{OP}}$ increase and then decrease, thus $R_{\mathrm{NP}}$ decreases and then increases (since the numerator $R_{\mathrm{OP}}$ 5 varies less than the denominator $R_{\mathrm{ON}}$ ).

In the literature, several studies report various values for the Redfield ratios. Often, these values also differ from those of Redfield himself, and this to a greater or lower extent (depending on the study, $R_{\mathrm{ON}}$ can range from 7 to $11, R_{\mathrm{OP}}$ can range from 95 to $190, R_{\mathrm{NP}}$ can range from 12 to 26 ). In general, they also vary geographically, depending both upon the area and upon the depth.

But the results (as well as the zones that are considered) are different depending on the methods used, and their associated explanations are more or less related to local phenomena. Thus, it is very difficult to compare results (Schneider et al., 2005). Some can be interpreted as similar to ours, others not.

25 For example, Anderson and Sarmiento (1994) calculated $R_{\mathrm{OP}}$ and $R_{\mathrm{NP}}$ in the south Atlantic $\left(20^{\circ} \mathrm{N}\right.$ to $\left.50^{\circ} \mathrm{S}\right)$, Indian $\left(20^{\circ} \mathrm{N}\right.$ to $\left.30^{\circ} \mathrm{S}\right)$ and south central Pacific (between $10^{\circ} \mathrm{N}$ and $30^{\circ} \mathrm{S}$ ) basins, between 400 and $4000 \mathrm{~m}$ depth. They found that the $R_{\mathrm{OP}}$ ratio is constant with depth and basin, at a value of $170 \pm 10$, whereas $R_{\mathrm{NP}}$ is constant with basin but exhibits a mid-depth minimum: in the $1000-3000 \mathrm{~m}$ zone, $R_{\mathrm{NP}} \cong 12 \pm 2$,
ESDD

6, 2383-2416, 2015

Characterization of

ocean

biogeochemical

processes

V. Guglielmi et al.

Title Page

Abstract

Introduction

Conclusions References

Tables

Figures

14

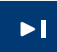

4

Back

Full Screen / Esc

Printer-friendly Version

Interactive Discussion 
above and below $R_{\mathrm{NP}} \cong 16 \pm 1$ (consequently, $R_{\mathrm{ON}}$ varies from approximately 11 to 14 at mid-depth).

Shaffer et al. (1999) analyzed data chosen in the same three ocean sectors (lowand mid-latitude Pacific, Indian and south Atlantic oceans) and obtained once again 5 ratios constant with basin. But they estimated that $R_{\mathrm{OP}}$ increases from about 140 at $750 \mathrm{~m}$ depth to about 170 at $1500 \mathrm{~m}$ and remains so deeper down. $R_{\mathrm{NP}}$ was found to decrease from about 15 at $750 \mathrm{~m}$ to about 12 at $1500-2000 \mathrm{~m}$, similar to results from Anderson and Sarmiento.

On a smaller scale, Hupe and Karstensen (2000) estimated $R_{\mathrm{OP}}$ and $R_{\mathrm{NP}}$ within the 10 Arabian Sea between 550 and $4500 \mathrm{~m}$. Both ratios were found to increase continuously with depth. In the 550-1200 m zone, $R_{\mathrm{OP}} \cong 139 \pm 7$ and $R_{\mathrm{NP}} \cong 14.4 \pm 0.2$. Between 1200 and $2000 \mathrm{~m}, R_{\mathrm{OP}} \cong 152 \pm 5$ and $R_{\mathrm{NP}} \cong 14.9 \pm 0.2$. Deeper than $2000 \mathrm{~m}, R_{\mathrm{OP}} \cong 158 \pm 5$ and $R_{\mathrm{NP}} \cong 15.3 \pm 0.2$. No mid-depth minimum was observed for $R_{\mathrm{NP}}$.

$\mathrm{Li}$ and Peng (2002) did not reveal any variation with depth but showed, for the Atlantic 15 Ocean divided into two zones: $45^{\circ} \mathrm{N}$ to $5^{\circ} \mathrm{N}$, and $5^{\circ} \mathrm{N}$ to $50^{\circ} \mathrm{S}$, a decrease of each ratio $R_{\mathrm{ON}}, R_{\mathrm{OP}}, R_{\mathrm{NP}}$ from north to south. In the northern zone, $R_{\mathrm{ON}} \cong 8.5 \pm 0.8, R_{\mathrm{OP}} \cong 137 \pm 7$ and $R_{\mathrm{NP}} \cong 16.1 \pm 1.0$. In the southern zone, $R_{\mathrm{ON}} \cong 8.4 \pm 0.3, R_{\mathrm{OP}} \cong 128 \pm 5$ and $R_{\mathrm{NP}} \cong$ $15.2 \pm 0.7$.

Today, the only agreed-upon conclusions are both the confirmation of the Redfield's concept (which has also been extended to other ecosystems than in the ocean), and the variability of these ratios depending upon the ocean area.

This variability seems natural: biogeochemical processes do not occur in the same way everywhere, even if they are somewhat homogenized by large-scale ocean circulation. In the upper layer of the ocean in contact with the atmosphere, the carbon and nutrients concentrations are far from being homogenized. At depth, nutrients are generally remineralized at about $1000 \mathrm{~m}$. The water masses movements and mixing, which tend to homogenize the nutrients and carbon concentrations, vary geographically.

ESDD

6, 2383-2416, 2015

Characterization of

ocean

biogeochemical

processes

V. Guglielmi et al.

\section{Title Page}

Abstract

Introduction

Conclusions References

Tables

Figures

14

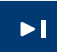

4

Back

Full Screen / Esc

Printer-friendly Version

Interactive Discussion 
Moreover, since the industrial era, the anthropogenic parts of carbon dioxide and also of nitrate and phosphate, are rising sharply. It is likely that this anthropogenic phenomenon accentuates the spatial variability of the Redfield ratios, and thus may add a temporal variability to these ratios.

\section{Conclusions}

Redfield ratios are prime indicators of the chemical composition of the ocean, which is governed by biological, chemical and physical processes. In the upper layer of the ocean, photosynthesis transforms carbon and nutrients into organic matter. This organic matter then remineralizes at depth, allowing the different elements to be en10 trained in a huge (large-scale) cycle through the convection movements and ocean circulation. In the context of climate change, these biogeochemical processes are very important because they determine how fast the ocean can absorb carbon dioxide from the atmosphere.

From the notion of water masses circulation and conservative tracers, we built the 15 Generalized Total Least-Squares estimator of the Redfield ratios $R_{\mathrm{ON}}$ and $R_{\mathrm{OP}}$. We have tested it, over the Atlantic Ocean from $60^{\circ} \mathrm{N}$ down to $45^{\circ} \mathrm{S}$. The results remain close to the nominal values of Redfield, with a variability consistent with some previous studies. The precise determination of the Redfield ratios is particularly important today in the context of global change, since they are used to calculate the concentrations 20 of anthropogenic carbon that penetrates into the ocean. The variability of these ratios demonstrates the need for a detailed study of their values prior their use, and the limitations of any mean that could be done.

Therefore, the method presented here could be particularly useful for future studies. While it respects the hydrological specificities of each ocean area, it can simply be

\section{ESDD}

6, 2383-2416, 2015

\section{Characterization of \\ ocean \\ biogeochemical \\ processes}

V. Guglielmi et al.

\section{Title Page}

Abstract

Conclusions

Tables

Figures

14

4

Back

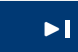

$\rightarrow 1$

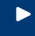

Close

Full Screen / Esc

Printer-friendly Version

Interactive Discussion divergence that an optimization algorithm would have), always constructing the same estimator. This is obviously subject to available measurements. 
The estimation of $R_{\mathrm{ON}}$ is based on the use of the conservative tracer NO, and therefore always needs the data of oxygen and nitrate. Similarly, the estimation of $R_{\mathrm{OP}}$ is based on the use of the conservative tracer PO, and therefore always needs the data of oxygen and phosphate. The other measurement data can be variable, as long as 5 they allow to build enough conservative tracers for the considered area.

For example here, to determine the Redfield ratios in the Atlantic Ocean, we used the "in situ" measurements: inevitably, oxygen, nitrate and phosphate (for NO and PO), then temperature, salinity and total alkalinity. From these "in situ" measurements, we built conservative tracers: conservative temperature, conservative salinity (so-called - preformed), and tracer $\operatorname{TrOCA}^{0}$ (it is the one that needs the measurements of total alkalinity). But the method would apply in the same way to different measurements and tracers.

The other advantage of this method, is that it also includes the anthropogenic part of the chemical elements involved (carbon, nitrate and phosphate). This is particularly im15 portant since today, the anthropogenic concentrations of carbon, nitrate and phosphate in the ocean are increasing.

\section{References}

Alvarez-Borrego, S., Guthrie, D., Culberson, C. H., and Kilho Park, P.: Test of Redfield's model for oxygen-nutrient relationships using regression analysis, Limnol. Oceanogr., 20, 795-805, 1975.

Anderson, L. A. and Sarmiento, J. L.: Redfield ratios of remineralization determined by nutrient data analysis, Global Biogeochem. Cy., 8, 65-80, 1994.

Broecker, W. S.: "NO", a conservative water-mass tracer, Earth Planet. Sc. Lett., 23, 100-107, 1974.

25 Castro, C. G., Pérez, F. F., Holley, S. E., and Rios, A. F.: Chemical characterisation and modelling of water masses in the Northeast Atlantic, Prog. Oceanogr., 41, 249-279, 1998.

Fieux, M.: L'océan planétaire, Les presses de l'ENSTA, Paris, 2010.
ESDD

6, 2383-2416, 2015

Characterization of

ocean

biogeochemical

processes

V. Guglielmi et al.

\section{Title Page}

Abstract

Introduction

Conclusions

References

Tables

Figures

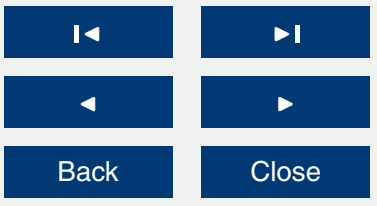

Full Screen / Esc

Printer-friendly Version

Interactive Discussion 
Goyet, C. and Brewer, P. G.: Biochemical properties of the oceanic carbon cycle, Modelling Oceanic Climate Interactions, in: NATO ASI Series, vol. I 11, Springer-Verlag, Berlin, 271297, 1993.

Goyet, C. and Touratier, F.: Challenges for present and future estimates of anthropogenic carbon in the Indian Ocean, in: Indian Ocean Biogeochemical Processes and Ecological Variability, edited by: Wiggert, J. D., Hood, R. R., Naqvi, S. W. A., Brink, K. H., and Smith, S. L., American Geophysical Union, Washington D.C., USA, 231-237, doi:10.1029/2008GM000754, 2009.

Goyet, C., Healy, R. J., and Ryan, J. P.: Global distribution of total inorganic carbon and total alkalinity below the deepest winter mixed layer depths, ORNL/CDIAC-127, NDP-076, Carbon Dioxide Information Analysis Center, Oak Ridge National Laboratory, US Department of Energy, Oak Ridge, Tennessee, doi:10.3334/CDIAC/otg.ndp076, 2000.

Hupe, A. and Karstensen, J.: Redfield stoichiometry in Arabian Sea subsurface waters, Global Biogeochem. Cy., 14, 357-372, 2000.

15 Key, R. M., Kozyr, A., Sabine, C. L., Lee, K., Wanninkhof, R., Bullister, J. L., Feely, R. A., Millero, F. J., Mordy, C., and Peng, T.-H.: A global ocean carbon climatology: results from Global Data Analysis Project (GLODAP), Global Biogeochem. Cy., 18, GB4031, doi:10.1029/2004GB002247, 2004.

$\mathrm{Li}$, Y.-H. and Peng, T.-H.: Latitudinal change of remineralization ratios in the oceans and its implication for nutrient cycles, Global Biogeochem. Cy., 16, 77-1-77-16, 2002.

Markovsky, I. and Van Huffel, S.: Overview of total least-squares methods, Signal Process., 87, 2283-2302, 2007.

Minster, J.-F., and Boulahdid, M.: Redfield ratios along isopycnal surfaces - a complementary study, Deep-Sea Res., 34, 1981-2003, 1987.

Placenti, F., Schroeder, K., Bonanno, A., Zgozi, S., Sprovieri, M., Borghini, M., Rumolo, P., Cerrati, G., Bonomo, S., Genovese, S., Basilone, G., Haddoud, D. A., Patti, B., El Turki, A., Hamza, M., and Mazzola, S.: Water masses and nutrient distribution in the Gulf of Syrte and between Sicily and Libya, J. Mar. Syst., 121-122, 36-46, 2013.

Redfield, A. C.: On the proportions of organic derivatives in sea water and in their relation to the composition of plankton, in: James Johnstone Memorial Volume, edited by: Daniel, R. J., University Press of Liverpool, Liverpool, UK, 176-192, 1934.
ESDD

6, 2383-2416, 2015

Characterization of

ocean

biogeochemical

processes

V. Guglielmi et al.

\section{Title Page}

Abstract

Introduction

Conclusions References

Tables

Figures

14

4

Back

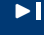

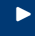

Close

Full Screen / Esc

Printer-friendly Version

Interactive Discussion 
Redfield, A. C., Ketchum, B. H., and Richards, F. A.: The influence of organisms on the composition of sea water, in: The Sea: Ideas and Observations on Progress in the Study of the Seas, Vol. 2, edited by: Hill, M. N., Interscience, New York, USA, 26-77, 1963.

Roy-Barman, M. and Jeandel, C.: Géochimie marine, Vuibert, Paris, 2011.

5 Schneider, B., Karstensen, J., Oschlies, A., and Schlitzer, R.: Model-based evaluation of methods to determine $\mathrm{C}: \mathrm{N}$ and $\mathrm{N}: \mathrm{P}$ regeneration ratios from dissolved nutrients, Global Biogeochem. Cy., 19, GB2009, doi:10.1029/2004GB002256, 2005.

Schroeder, K., Gasparini, G. P., Borghini, M., Cerrati, G., and Delfanti, R.: Biogeochemical tracers and fluxes in the Western Mediterranean Sea, spring 2005, J. Mar. Syst., 80, 8-24, 102010.

Shaffer, G., Bendtsen, J., and Ulloa, O.: Fractionation during remineralization of organic matter in the ocean, Deep-Sea Res., 46, 185-204, 1999.

Takahashi, T., Broecker, W. S., and Langer, S.: Redfield ratio based on chemical data from isopycnal surfaces, J. Geophys. Res., 90, 6907-6924, 1985.

Tomczak, M.: Some historical, theoretical and applied aspects of quantitative water mass analysis, J. Mar. Res., 57, 275-303, 1999.

Touratier, F. and Goyet, C.: Applying the new TrOCA approach to assess the distribution of anthropogenic $\mathrm{CO}_{2}$ in the Atlantic Ocean, J. Mar. Syst., 46, 181-197, 2004.

Touratier, F., Azouzi, L., and Goyet, G.: CFC-11, $\Delta^{14} \mathrm{C}$ and ${ }^{3} \mathrm{H}$ tracers as a means to assess anthropogenic $\mathrm{CO}_{2}$ concentrations in the ocean, Tellus B, 59, 318-325, 2007.

Touratier, F., Guglielmi, V., Goyet, C., Prieur, L., Pujo-Pay, M., Conan, P., and Falco, C.: Distributions of the carbonate system properties, anthropogenic $\mathrm{CO}_{2}$, and acidification during the 2008 BOUM cruise (Mediterranean Sea), Biogeosciences Discuss., 9, 2709-2753, doi:10.5194/bgd-9-2709-2012, 2012.
ESDD

6, 2383-2416, 2015

Characterization of

ocean

biogeochemical

processes

V. Guglielmi et al.

Title Page

Abstract

Introduction

Conclusions References

Tables

Figures

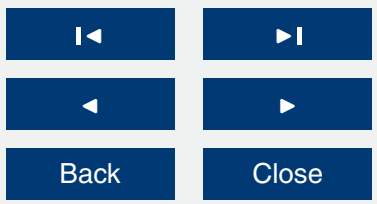

Full Screen / Esc

Printer-friendly Version

Interactive Discussion 


\section{ESDD}

6, 2383-2416, 2015

Characterization of

ocean

biogeochemical

processes

V. Guglielmi et al.

\section{Title Page}

Abstract

Introduction SASTW upper NADW lower NADW AAIW lower NADW AABW

$20^{\circ} \mathrm{N}-5^{\circ} \mathrm{N}$ a surface water

SASTW AAIW
NACW upper NADW AABW

\begin{tabular}{|c|c|c|c|c|}
\hline $5^{\circ} \mathrm{N}-20^{\circ} \mathrm{S}$ & $\begin{array}{l}\text { a surface water } \\
\text { SASTW } \\
\text { SACW }\end{array}$ & $\begin{array}{l}\text { SASTW } \\
\text { AAIW } \\
\text { upper NADW }\end{array}$ & $\begin{array}{l}\text { AAIW } \\
\text { upper NADW } \\
\text { lower NADW } \\
\text { AABW }\end{array}$ & $\begin{array}{l}\text { AAIW } \\
\text { upper NADW } \\
\text { lower NADW } \\
\text { AABW }\end{array}$ \\
\hline $20^{\circ} \mathrm{S}-45^{\circ} \mathrm{S}$ & $\begin{array}{l}\text { a surface water } \\
\text { SASTW } \\
\text { AAIW }\end{array}$ & $\begin{array}{l}\text { SASTW } \\
\text { AAIW } \\
\text { upper NADW }\end{array}$ & $\begin{array}{l}\text { AAIW } \\
\text { upper NADW } \\
\text { lower NADW } \\
\text { AABW }\end{array}$ & $\begin{array}{l}\text { AAIW } \\
\text { upper NADW } \\
\text { lower NADW } \\
\text { AABW }\end{array}$ \\
\hline
\end{tabular}

14

4

Back

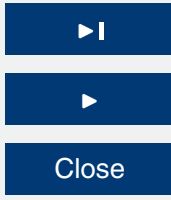

Full Screen / Esc

Printer-friendly Version

Interactive Discussion 
Table 2. Redfield ratios, within each studied ocean area.

\begin{tabular}{|c|c|c|c|c|c|c|c|c|c|c|c|c|}
\hline & \multirow{2}{*}{\multicolumn{3}{|c|}{$50-500 \mathrm{~m}$}} & \multirow{2}{*}{\multicolumn{3}{|c|}{$500-1750 \mathrm{~m}$}} & \multicolumn{6}{|c|}{$1750 \mathrm{~m}$-bottom } \\
\hline & & & & & & & & We & & & East & \\
\hline & $R_{\mathrm{ON}}$ & $R_{\mathrm{OP}}$ & $R_{\mathrm{NP}}$ & $R_{\mathrm{ON}}$ & $R_{\mathrm{OP}}$ & $R_{\mathrm{NP}}$ & $R_{\mathrm{ON}}$ & $R_{\mathrm{OP}}$ & $R_{\mathrm{NP}}$ & $R_{\mathrm{ON}}$ & $R_{\mathrm{OP}}$ & $R_{\mathrm{NP}}$ \\
\hline $60^{\circ} \mathrm{N}-20^{\circ} \mathrm{N}$ & 7.3 & 127 & 17.4 & 8.8 & 131 & 14.9 & 8.1 & 122 & 15.1 & 8.1 & 124 & 15.3 \\
\hline $20^{\circ} \mathrm{N}-5^{\circ} \mathrm{N}$ & 7.2 & 127 & 17.6 & 8.7 & 132 & 15.2 & 7.6 & 123 & 16.2 & 7.7 & 125 & 16.2 \\
\hline $5^{\circ} \mathrm{N}-20^{\circ} \mathrm{S}$ & 7.1 & 130 & 18.3 & 8.7 & 133 & 15.3 & 7.2 & 126 & 17.5 & 7.4 & 126 & 17.0 \\
\hline $20^{\circ} \mathrm{S}-45^{\circ} \mathrm{S}$ & 7.7 & 123 & 16.0 & 9.1 & 132 & 14.5 & 8.2 & 125 & 15.2 & 8.2 & 126 & 15.4 \\
\hline
\end{tabular}

ESDD

6, 2383-2416, 2015

Characterization of ocean

biogeochemical processes

V. Guglielmi et al.

Title Page

Abstract

Introduction

Conclusions

References

Tables

Figures

14

4

Back

Full Screen / Esc

Printer-friendly Version

Interactive Discussion 


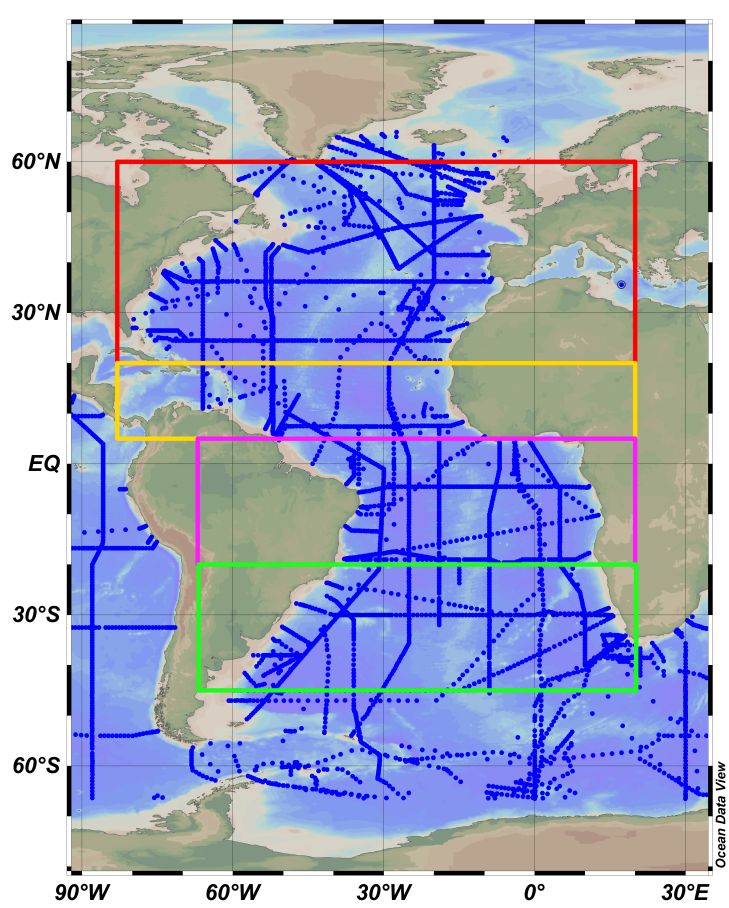

\section{ESDD}

6, 2383-2416, 2015

Characterization of ocean

biogeochemical processes

V. Guglielmi et al.

Title Page

Abstract

Introduction

Conclusions

References

Tables

Figures

14

Back

Full Screen / Esc

Figure 1. The Atlantic Ocean.

Printer-friendly Version

Interactive Discussion

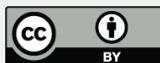

